\title{
Effect of Floods Explosion and Chemical Action on Fish Farming in Ibadan Metropolis, Oyo State, Nigeria
}

\author{
Ayinde Alani Ezekiela, Timothy Abiodun Adebayoa, Abosede Olufunmi Adewoyea, Akinniran Taiwo \\ Nurenia
}

\begin{abstract}
This paper analyzed the effect of flood and socio-economic problems on fish farming in Ibadan Metropolis, Oyo State, Nigeria. A multistage random sampling technique was used to select 80 fish farmers in the state. Both primary and secondary data were collected and analyzed using descriptive statistics to analyze the socio-economic characteristics of the fish farmers, cost and returns analysis was done to determine the profitability ratios of the fish farming in the study areas. The mean age analyzed was 45\%. The result of the cost and returns analysis showed that Average Total Cost (ATC) of N1, 500,517.5 was incurred, Total Revenue (TR) of N, 138,659,400 was realized and a returning Gross Margin (GM) of N was 64,885,800 by fish farmers. The major constraints encountered by fish farmers were flooding that wash away fish, deposit heavy metals such as ammonia $\left(\mathrm{NH}_{4}\right)$, lead, copper, cadmium, arsenic, etc., that can result to the death of fish in the fishponds and rivers when flood overflowing. The methodology applied for the flood examination includes site visits, interviews of affected fish farmers, and analyses of flood data collected during the field examination.
\end{abstract}

\section{Keywords}

Fish, food, security, flood, management

The layer of sedimentation depends on the strength of flood and velocity of floods overflowing. Anaerobic decomposition mostly gives rise to gases like $\mathrm{CO}_{2}$, $\mathrm{CH}_{4}$, and $\mathrm{H}_{2} \mathrm{~S}$. Flooding is a problem to most people, though it can be quite beneficial. This is because, nature benefits more from natural floods than not having them at all, natural floods become a disaster when flood waters occur in areas populated by humans and in areas of significant human development. Moreover, when left in its natural state, the benefits of floods outweigh the adverse effects, too much sand deposit along rivers will do the opposite for farmers that maintain their crops along rivers, and they should not feel threatened by yearly flooding. One way to mitigate the effects of flooding is to ensure that all areas that are vulnerable are identified and adequate precautionary measures are taken to ensure either or all of adequate preparedness, effective response, quick recovery, and effective prevention, this can be done by studying the hydrological cycle as presented below (see Figure 3). This gives their farm lands better soil consistencies and keeps their land fertile resulting to

\footnotetext{
aLadoke Akintola University of Technology, Nigeria

Correspondent Author:

Ezekiel Ayinde Alani, Department of Agricultural Economics, Faculty of Agricultural Sciences, Ladoke Akintola University of Technology, P.M.B 4000, Ogbomoso, Oyo State, Nigeria
} 
better harvest each year. This paper analyzed the flood, and socio-economic problems on fish farming in Ibadan Metropolis in Nigeria. A multistage random sampling technique was used to select 80 fish farmers in the state. Primary data were collected and analyzed using descriptive statistics to analyze the socio-economic characteristics of the fish farmers, cost and returns analysis was used to determine the profitability ratios of the fish farming in the study areas. The mean age analyzed was $45 \%$. The result of the cost and returns analysis showed that Average Total Cost (ATC) of N1, $500,517.5$ was incurred, Total Revenue (TR) of N, $138,659,400$ was realized, and a returning Gross Margin (GM) of $\mathrm{N}$ was $64,885,800$ by fish farmers. The major constraints encountered by farmers were flooding, high cost of fish feed, and low quality of feeds. The methodology applied includes site visits, interviews of fish farmers, and analyses of flood data collected during the field examination. Instead of preventing the natural flow of river floods, it might be beneficial in the long run to allow the flood waters to encroach into their lands (Bradshaw et al. 2007). Floodwater washed away fish from fishponds, estimated at millions of naira. Poultry farmers also indicated that the floodwater damaged their poultry farms; many livestocks were washed away, particularly on farms close to riverbanks, most of fishponds water turns acidic with occurrence of flooding. Floods often cause damage to homes and businesses if they are placed in natural flood plains of rivers. While flood damage can be virtually eliminated by moving away from rivers and other bodies of water, people have lived and worked by the water to seek sustenance and capitalize on the gains of cheap and easy travel and commerce by being near water. That humans continue to inhabit areas threatened by flood damage is evidence that the perceived value of living near the water exceeds the cost of repeated periodic flooding (Lenat, Penrose, and Eagleson 1981). Flood is a large amount of water covering an area that is usually dry. It is an overflowing of a great body of water over land not usually submerged. Nwafor (2006) defined flood as a natural hazard like drought and desertification which occurs as an extreme hydrological (run-off) event, according to Abam (2006), flood is a large volume of water which arrives at, and occupies the stream channel and its flood plain in a time too short to prevent damage to economic activities including homes. Floods are among the most devastating natural disasters in the world, claiming more lives and causing more property damage than any other natural phenomena. Flooding is the most common environmental hazard in Nigeria and it has destructive tendencies. Although not leading in terms of claiming lives, flood affects and displaces more people than any other disasters; it also causes more damage to properties. At least $20 \%$ of the population is at risk from one form of flooding or another (Etuonovbe 2011).

\section{STATEMENT OF THE PROBLEM}

Flooding is an extreme weather condition naturally caused by rising global temperature, resulting in heavy downpour, thermal expansion of the ocean, and glacier melt, which can also lead to rise in sea level, thereby causing salt water to inundate coastal lands. It is one of the most common environmental hazards and it regularly claims over 20,000 lives in a year and adversely affects around 75 million people worldwidely. Flooding is one of the most common environmental issues in the southern and the eastern part of Nigeria alongside with deforestation and erosion. It has caused serious danger to people's lives and properties across the world; resulting into about one third of all deaths, injuries, and one third of all danger from natural disasters. It also causes death of fishponds and rivers. In Nigeria, flooding had forced millions of people to leave their homes, destroying life and properties, polluting water resources and increasing disease outbreaks. The Ogumpa Rivers flood in 1983 claimed 30 lives; uncountable fish died, 
destroyed many houses and left 15,000 people homeless. In the light of these, the research intends to address the following questions:

(1) What are the socio-economic characteristics of the fish farmers in the study area?

(2) What are the causes of flood in the study area?

(3) What are the effects of flood on fish farming in the study area?

(4) How profitable is fish farming in the study area?

\section{OBJECTIVES OF THE STUDY}

Generally, this study examined the effect and socio-economic problems of flood explosion on fish farming in the study area.

The specific objectives are:

(1) To identify the socio-economic characteristics of the fish farmers in the study area;

(2) To identify the causes of flood in the study area;

(3) To determine the economic and environmental effect of flood on fish farming in the study area;

(4) To determine the profitability of fish farming in the study area.

\section{HYPOTHESIS OF THE STUDY}

$\mathrm{H}_{\mathrm{o}}$ : There is no significant relationship between flood explosion and fish farming in the study area.

\section{JUSTIFICATION OF THE STUDY}

This study is aimed at providing solution to the effects of flood on fish farming in the study areas since the flooding incidents in some parts of the country are taking a toll on fish farms. For instance, incessant flooding in Ibadan Metropolis, the present calamity would seriously affect fish production as supply in the market would be greatly affected, then there is need to investigate the incidence of flooding in Ibadan Metropolis and to create an open end to this study.

\section{RESEARCH METHODOLOGY}

This study was carried out in the metropolitan city of Ibadan which is the capital city of Oyo state, Nigeria. It is located on latitude $7023^{\prime} 47^{\prime \prime} \mathrm{N}$ and longitude $3055^{\prime}$ ' 0 'E (see Figure 1). It is the largest metropolitan area in Africa with a population of about 2,338,659 according to the 2006 census, giving a population density of 816.63 person/ $\mathrm{km}$ square. Ibadan is located in southwestern Nigeria in the southeastern part of Oyo state, about $128 \mathrm{~km}$ inland northeast of Lagos and $530 \mathrm{~km}$ southwest of Abuja, the federal capital, and a prominent transit point between the coastal region and the areas to the north. The city's total area is about $3,080 \mathrm{~km}^{2}$ (Wikipedia 2014). It is a tropical rainforest which makes it suitable for catfish farming. There are 11 local governments in Ibadan metropolitan area, and they are: Ibadan north, Ibadan north-east, Ibadan north-west, Ibadan south-east, Ibadan south-west, Akinyele, Egbeda, Ibarapa central, Ibarapa east, Ido and Oluyole (see Figure 2). The historical date of the first flooding in Ibadan has been a subject of debate, the first flooding occurred in Ibadan in 1902, Adebayo (2012) recorded that flooding has been a recurrent decimal in Ibadan with recorded occurrences in 1948, 1955, 1961, 1963, 1978, 1980, 1985, 1987, and 1990 claiming over 35,000 lives and properties worth millions of naira, with the major sources of this flooding being Ogunpa and Kudeti streams (see Figure 6). Ibadan has recorded varying degrees of flooding. For instance, there was flooding in the watersheds of Ogunpa and Kudeti streams (see Table 13), (one of the two major streams in Ibadan) in 1955, 1960, 1961, 1963, 1969, 1978, and 1980 led to destruction of many houses (see Figure 5 and Table 14). The flooding of 1969 is unique because it resulted from a mere $25.4 \mathrm{~mm}$ rainfall. The multi-criteria flood risk/vulnerability mapping approach showed the spatial distribution of the different risk criteria (see Figure 4). 
The study area was chosen because of thriving aquaculture industry across all the local governments. A multistage sampling procedure was used to select 80 respondents. The first stage involved selection of an association of catfish farmers in Ibadan metropolis; this included the Catfish Association of Nigeria (CAFAN) and Aquaculture Farmers Association of Nigeria (AFAN) being the umbrella body of catfish farmers. This was followed by purposive selection of two local government areas due to high production of catfish in the area. The third stage involved random selection of 80 catfish farmers. Primary data were obtained through the use of well-structured questionnaires, while secondary data were obtained through internet, books, magazines, books, etc. The catfish farmers were asked to provide data on the quantity of output produced, input used, cost of production, and also on the prices of inputs and flooding experience. Information was also obtained on the socio-economical characteristics such as age, sex, marital status, level of literacy, cost of land, cost of labour, number of ponds, and years of experience in catfish farming.

\section{RESULTS AND DISCUSSIONS}

Descriptive analysis was used to analyze the socio-economic characteristics of the respondents. It involves the use of frequency tables, percentage, and mean. Cost and returns analysis was used to determine the profitability of catfish production (see Table 11a). The profitability analyses that will be employed are Fixed Cost (FC), Variable Cost (VC), Total Cost (TC), TR, GM, and Profit.

$\mathrm{TC}=\mathrm{TVC}($ Total Variable Cost $)+\mathrm{TFC}($ Total Fixed Cost).

$$
\begin{aligned}
& \mathrm{TR}=\mathrm{P} \times \mathrm{Q}[\mathrm{P}=\text { Price and } \mathrm{Q}=\text { Total Output }(\mathrm{kg})] \\
& \mathrm{GM}=\mathrm{TR}-\mathrm{TVC} \\
& \text { Profit }=\mathrm{GM}-\mathrm{TFC} \text { or Profit }=\mathrm{TR}-\mathrm{TC} \\
& \text { In addition to the above illustrations, the }
\end{aligned}
$$
profitability can also be determined with the uses of ratio analysis such as:
Expense Structure Ratio (ESR) $=$ FC $/$ TC

Benefit Cost Ratio $(\mathrm{BCR})=\mathrm{TR} / \mathrm{TC}$

Gross Revenue Ratio (GRR) $=\mathrm{TC} / \mathrm{TR}$

Rate of Return $=$ Net Return $/ \mathrm{TC}$

Regression analysis was used to identify the effect of flood explosion on fish farming and factors that influence catfish production. All the functional forms were tested before choosing the double $\log$ which is the best fit. The production function was expressed as a function of the explanatory variables. It showed the relationship between dependent variable $(\mathrm{Y})$ and

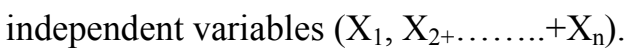

A hypothetical Cobb Douglas functional form was given:

In $\mathrm{Y}=\mathrm{b}_{0}+\mathrm{b}_{1} \ln \mathrm{X}_{1}+\mathrm{b}_{2} \ln \mathrm{X}_{2}+\mathrm{b}_{3} \ln \mathrm{X}_{3}+\mathrm{b}_{4} \ln \mathrm{X}_{4}+$ $\mathrm{b}_{5} \ln \mathrm{X}_{5}+\mathrm{b}_{6} \ln \mathrm{X}_{6}+\mathrm{b}_{7} \ln \mathrm{X}_{7}+\mathrm{b}_{8} \ln \mathrm{X}_{8}+\mathrm{b}_{9} \ln \mathrm{X}_{9}+$ $\mathrm{b}_{10} \ln \mathrm{X}_{10}+\mathrm{b}_{11} \ln \mathrm{X}_{11}+\mathrm{E}$

$\mathrm{Y}=$ Revenue

$\mathrm{X}_{1}-\mathrm{X}_{9}=$ Independent variables

$\mathrm{b}_{0}=$ Constant term

$\mathrm{b}_{1}-\mathrm{b}_{11}=$ Parameters that were estimated

$\mathrm{X}_{1}=$ Age

$\mathrm{X}_{2}=$ Gender

$\mathrm{X}_{3}=$ Household size

$\mathrm{X}_{4}=$ Cost of land

$\mathrm{X}_{5}=$ Cost of fingerling

$\mathrm{X}_{6}=$ Cost of labour

$\mathrm{X}_{7}=$ Cost of feed

$\mathrm{X}_{8}=$ Cost of transportation

$\mathrm{X}_{9}=$ Cost of drugs

$\mathrm{X}_{10}=$ Effect of flood

$\mathrm{X}_{11}=$ Number of ponds

$\mathrm{E}=$ Error term

\section{Age of Respondents}

Table 1 below showed the distribution of fish farmers with respect to their socio-economic characteristic. Most (27.5\%) of the fish farmers were within the age bracket of 40-49 years, $20 \%$ were within 30-39 years, $18.8 \%$ were within $50-59$ years, $13.8 \%$ were within $60-69$ years, $12.5 \%$ were within $20-29$ years while $7.5 \%$ were above 70 years, with the 
mean age of total respondents being 47.15. According to Sikiru et al. (2009), the age bracket (30-39) is a productive age which predicts better future for catfish production.

\section{Gender}

Table 2 showed that sex plays a very important role in fish farming and agriculture, in terms of property acquisition, for example, fixed assets like land and machines. Majority (82.5\%) of the fish farmers were male while $17.5 \%$ were female. This result can be justified by the assertion of Brummett et al. (2010), that fisheries activities are mostly dominated by men.

\section{Marital Status}

Ekong (2003) pointed out that marriage in our society is highly cherished. This was further confirmed by the report of Fakoya (2000) and Oladoja, Adedoyin, and Adeokun (2008), who asserted that marriage confers some level of responsibility and commitment on individuals who are married. In this study, it was discovered that majority of the farmers were married (70\%), producing medium-large household size, which could be of great importance to labour management, while very few were single, widowed, and separated (see Table 3).

\section{Level of Education}

Table 4 showed that $67.5 \%$ had tertiary education. This means that fish farming is dominated by the educated class and mostly by those with high level of education. This is so because fish farming requires a lot of technical and scientific knowledge to be successfully undertaken.

\section{Household Size}

Table 5 showed that the household size of those that ranged between 5-8 had the highest percentage of 57.5 with a mean of 5.68. This shows that there were enough hands (family labour) engaged to carry out fish farming operations. This result agrees with Adebayo (2012), that family size can serve as source of free and cheap labour.

\section{Years of Experience in Fish Farming}

Table 6 showed that $76.3 \%$ of the respondents have 0-9 years of experience with a mean value of 8.1 . This shows that the catfish farmers are relatively new in the enterprise. This agrees with Williams, Kareem, and Ojolowo (2012), that the ability to manage fish pond efficiently depends on the years of experience and this is directly related to the total productivity of the farm. It also revealed that $18.8 \%$ had fish farming experience ranging between 10-19 years, $2.5 \%$ had between $20-29$ years, while only $2.5 \%$ had above 40 years' experience in fish farming. As a result, the respondents with the highest number of years of experience should have good skills and better approaches to fish farming business. The respondents with longer years of experience were also able to forecast market situation in which they sell their products at higher prices. Those with less years of experience, especially with less than 10 years faced many risks in the early days of their fish farming business.

\section{Causes of Flood}

Table 7 showed that the most common type of rain fall is the convective rainfall $(100 \%)$. It also revealed that majority $(91.5 \%)$ of the respondents made use of gentle sloped land, which is the most efficient for fish farming. Higher percentage of the study area (78.8\%) has rivers, which aid constant supply of water. This also revealed that $73.8 \%$ of the study area has vegetative cover. Only a small number of respondents $(20 \%)$ were closed to dams. The table also showed that majority of the respondents dispose wastes by using refuse dumpsite with a percentage of 50.9. This is followed by dumping in the river $(24.5 \%)$, while others dispose their wastes through dumping in the gutter and burning. 


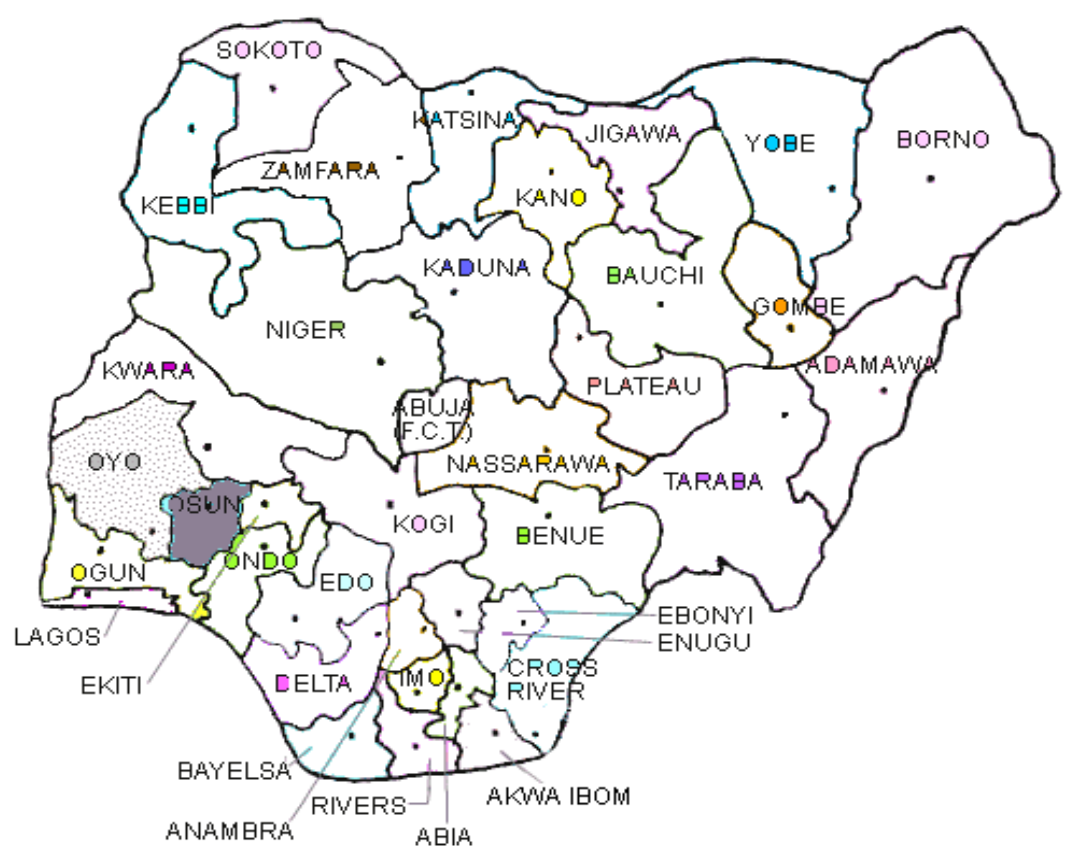

Figure 1. Map of Nigeria Showing Oyo State Where the Study Areas Are Located. Source: World Atlas Travel.

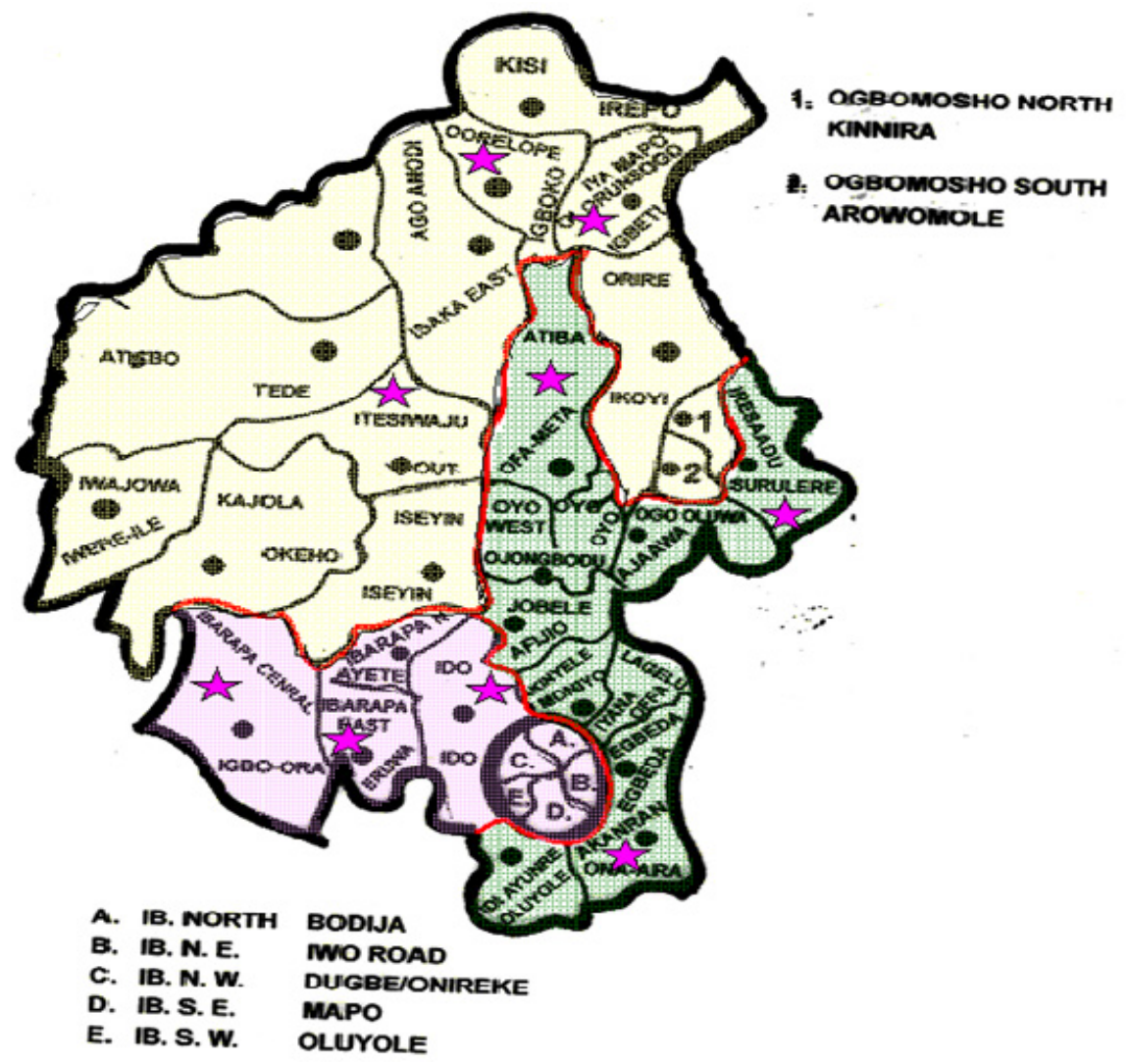

Figure 2. Map of Oyo State Showing the Selected Local Government Areas in Ibadan Metropolis. Source: Website of Oyo State Government. 


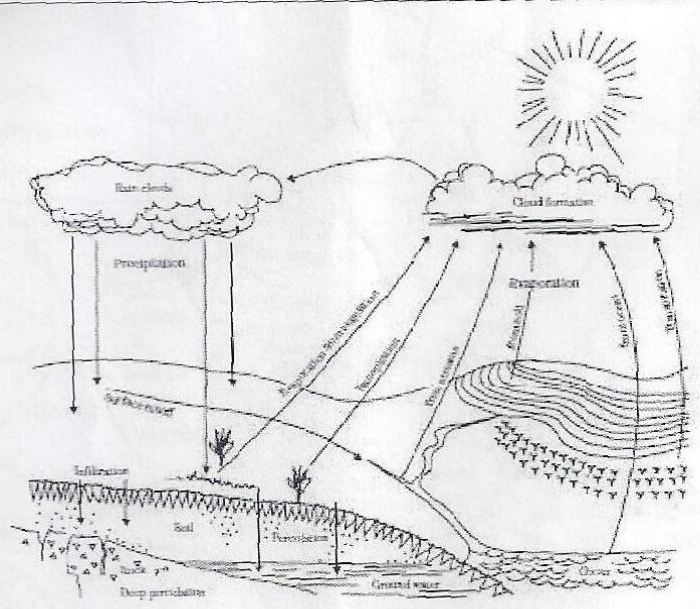

Figure 3. The Hydrologic Cycle (NEH 2007). Source: Field Survey, 2014.

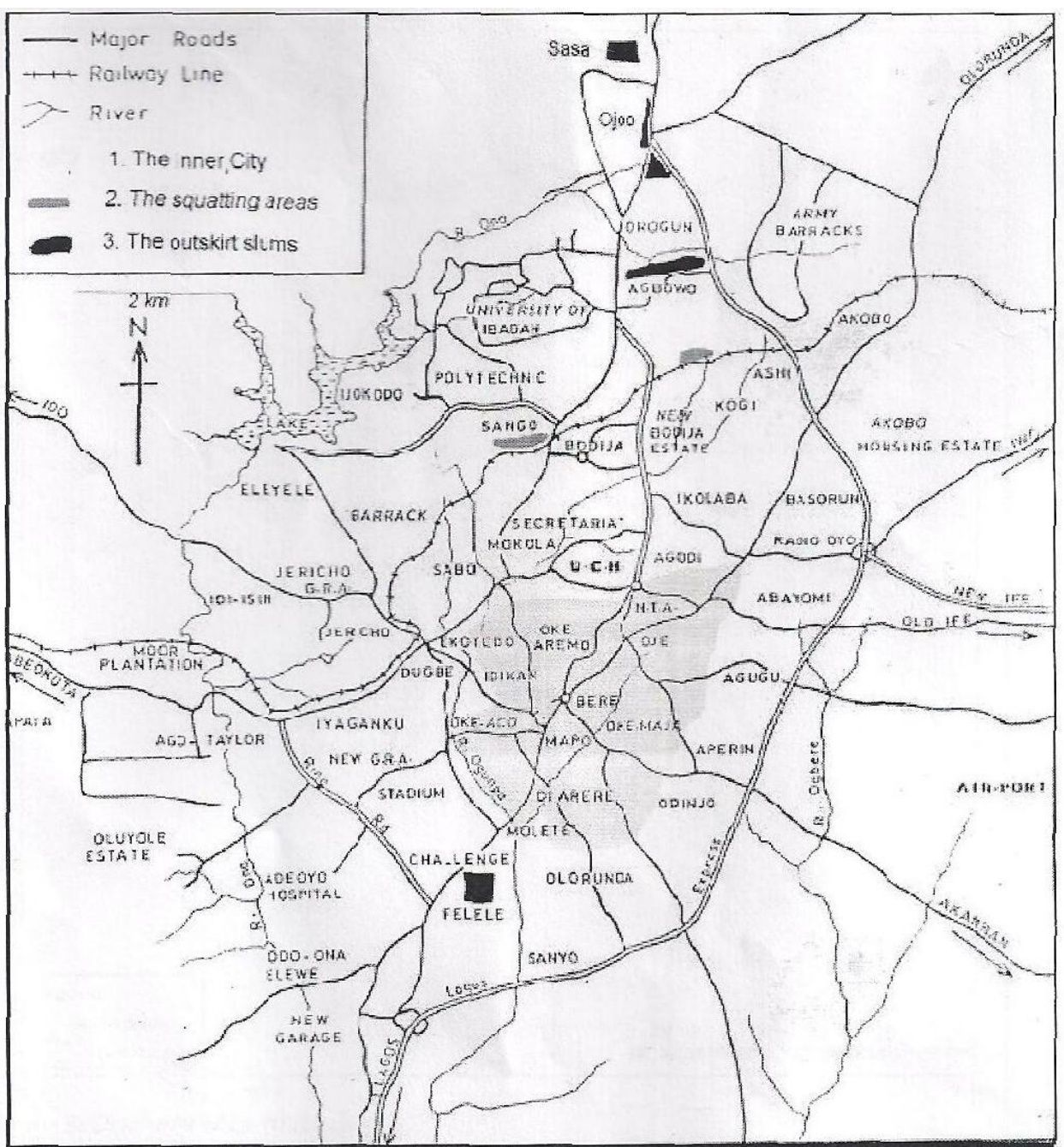

Figure 4. Drainage Map of Ibadan Metropolis. Source: Field Survey, 2014. 


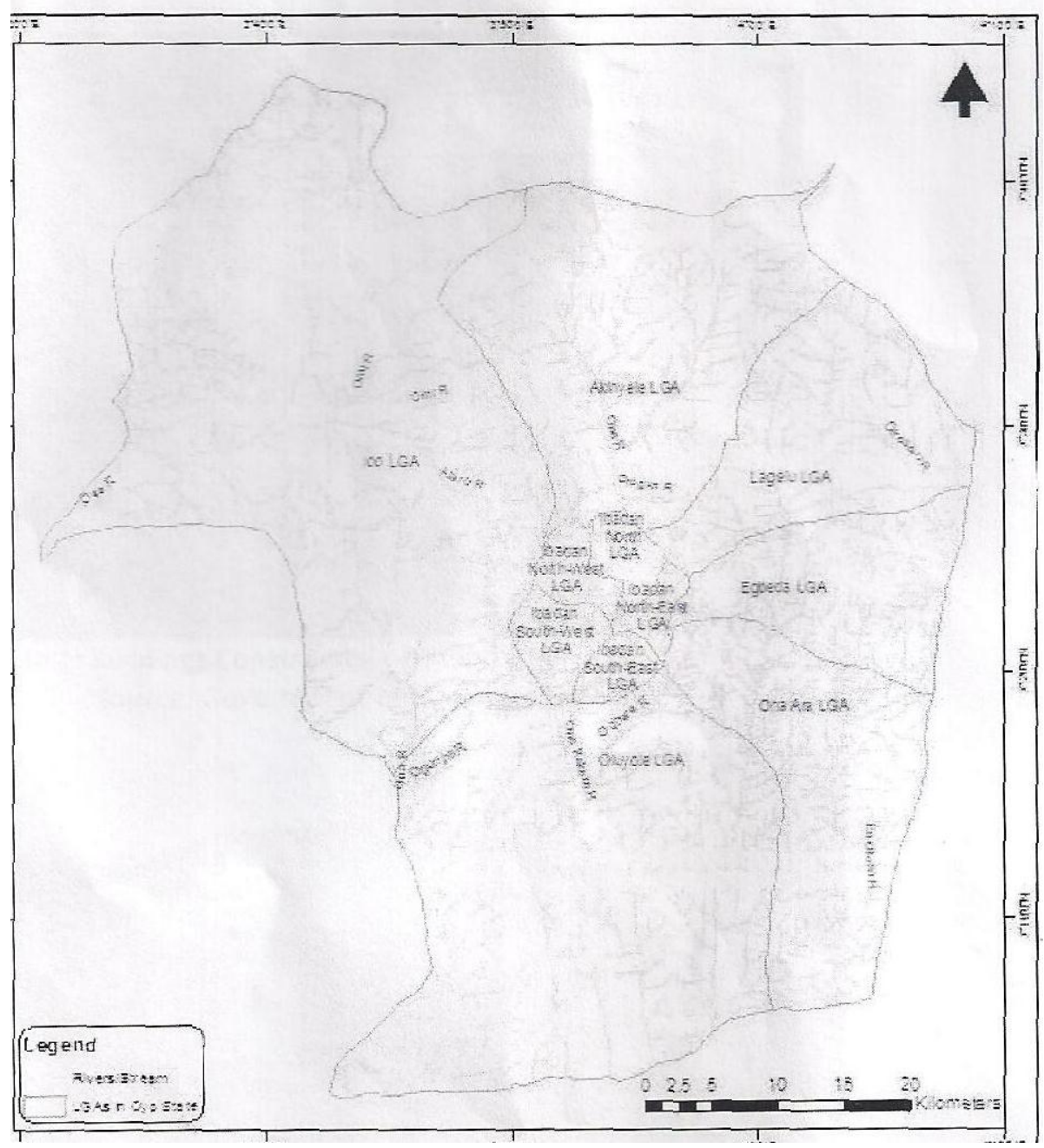

Figure 5. Map Showing Areas Affected by Flood. Source: Field Survey, 2014.
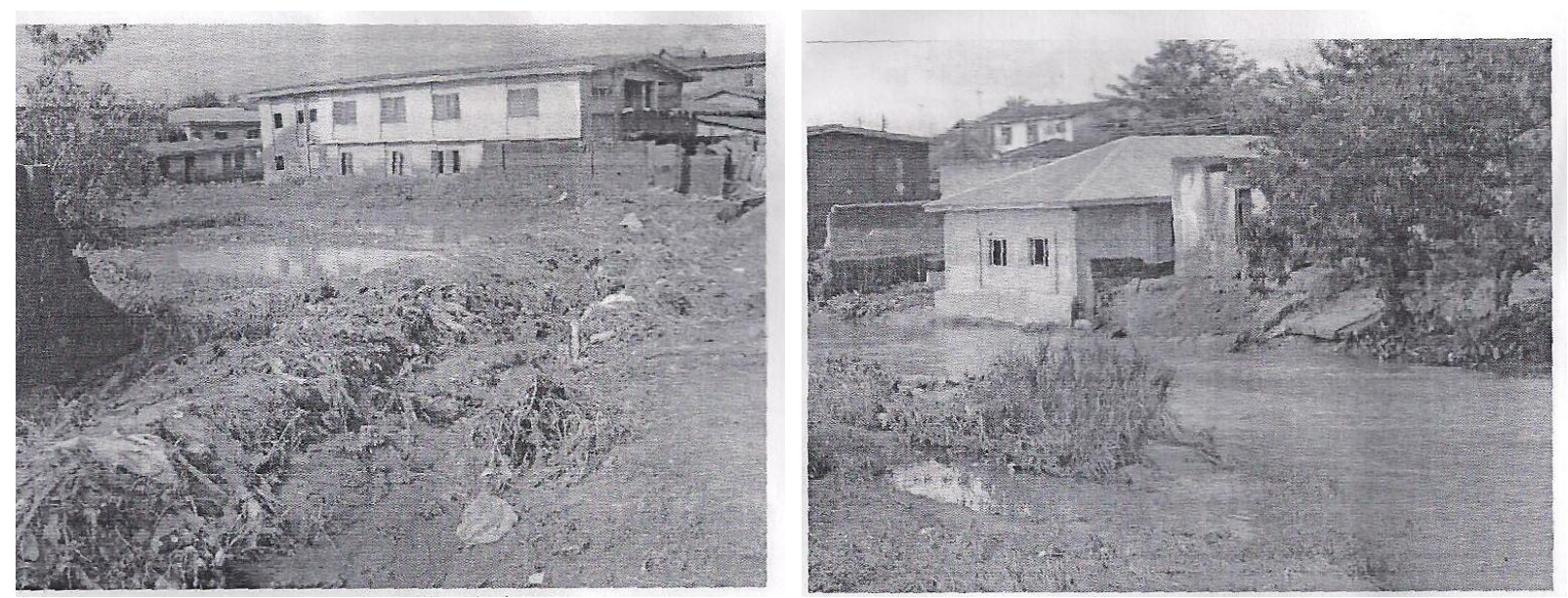

Figure 6. Houses Affected by the Flood in the Study Area. Source: Field Survey, 2014. 
Table 1. Distribution of Respondents Based on Their Age

\begin{tabular}{lll}
\hline Age & Frequency & Percentage (\%) \\
\hline $20-29$ & 10 & 12.5 \\
$30-39$ & 16 & 20.0 \\
$40-49$ & 22 & 27.5 \\
$50-59$ & 15 & 18.8 \\
$60-69$ & 11 & 13.8 \\
70 and above & 6 & 7.5 \\
Total & 80 & 100 \\
\hline
\end{tabular}

Note: Source: Field Survey 2014.

Table 2. Distribution of Respondents Based on Their Gender

\begin{tabular}{lll}
\hline Gender & Frequency & Percentage (\%) \\
\hline Male & 66 & 82.5 \\
Female & 14 & 17.5 \\
Total & 80 & 100 \\
\hline
\end{tabular}

Note: Source: Field Survey 2014.

Table 3. Distribution of Respondents by Their Marital Status

\begin{tabular}{lll}
\hline Marital status & Frequency & Percentage (\%) \\
\hline Single & 18 & 22.5 \\
Married & 56 & 70.0 \\
Divorced & 2 & 2.5 \\
Widowed & 4 & 5.0 \\
Total & 80 & 100 \\
\hline
\end{tabular}

Note: Source: Field Survey 2014.

Table 4. Distribution of Respondents Based on Their Level of Education

\begin{tabular}{lll}
\hline Level of education & Frequency & Percentage (\%) \\
\hline No education & 1 & 1.3 \\
Primary education & 6 & 7.5 \\
Secondary education & 19 & 23.8 \\
Tertiary education & 54 & 67.5 \\
Total & 80 & 100 \\
\hline
\end{tabular}

Note: Source: Field Survey 2014.

Table 5. Distribution of Respondents Based on Their Household Size

\begin{tabular}{lll}
\hline Household size & Frequency & Percentage (\%) \\
\hline $1-4$ & 25 & 31.3 \\
$5-8$ & 46 & 57.5 \\
9 and above & 9 & 11.3 \\
Total & 80 & 100 \\
\hline
\end{tabular}

Note: Source: Field Survey 2014. 
Table 6. Distribution of Respondents Based on Their Years of Experience in Fish Farming

\begin{tabular}{lll}
\hline Year of experience & Frequency & Percentage (\%) \\
\hline $0-9$ & 61 & 76.3 \\
$10-19$ & 15 & 18.8 \\
$20-29$ & 2 & 2.5 \\
$30-39$ & 0 & 0 \\
40 and above & 2 & 2.5 \\
Total & 80 & 100 \\
\hline
\end{tabular}

Note: Source: Field Survey 2014.

Table 7. Distribution of the Probable Causes of Flood

\begin{tabular}{|c|c|c|}
\hline Type of rainfall & Frequency & Percentage (\%) \\
\hline Convective & 80 & 100 \\
\hline Strati form & 0 & 0 \\
\hline Orographic & 0 & 0 \\
\hline Total & 80 & 100 \\
\hline Topography of land & Frequency & Percentage (\%) \\
\hline Flat & 6 & 7.5 \\
\hline Gentle slope & 73 & 91.5 \\
\hline Steep slope & 0 & 0 \\
\hline Steep and gentle slope & 1 & 1.3 \\
\hline Total & 80 & 100 \\
\hline Presence of vegetation & Frequency & Percentage (\%) \\
\hline Yes & 59 & 73.8 \\
\hline No & 21 & 26.3 \\
\hline Total & 80 & 100 \\
\hline Presence of river & Frequency & Percentage (\%) \\
\hline Yes & 63 & 78.8 \\
\hline No & 17 & 21.3 \\
\hline Total & 80 & 100 \\
\hline Presence of dam & Frequency & Percentage (\%) \\
\hline Yes & 16 & 20 \\
\hline No & 64 & 80 \\
\hline Total & 80 & 100 \\
\hline Methods of waste disposal & Frequency & Percentage (\%) \\
\hline Dumping in the river & 20 & 25 \\
\hline Dumping in the gutter & 11 & 14 \\
\hline Refuse dumpsite & 41 & 51.3 \\
\hline Others (burning) & 8 & 10 \\
\hline Total & 80 & 100 \\
\hline
\end{tabular}

Note: Source: Field Survey 2014.

Table 8. Distribution Table Showing Number of Ponds Unit Owned

\begin{tabular}{lll}
\hline Number of ponds unit & Frequency & Percentage (\%) \\
\hline $1-5$ & 70 & 87.5 \\
$6-10$ & 7 & 8.8 \\
$11-15$ & 3 & 3.8 \\
$16-20$ & 0 & 0 \\
Total & 80 & 100 \\
\hline
\end{tabular}

Note: Source: Field Survey 2014. 
Table 9. Frequency and Percentage Distribution Table Based on the Type of Rearing Facilities

\begin{tabular}{lll}
\hline Rearing facilities & Frequency & Percentage (\%) \\
\hline Earthen pond only & 65 & 81.3 \\
Concrete pond only & 1 & 1.3 \\
Both & 14 & 17.5 \\
Total & 80 & 100 \\
\hline
\end{tabular}

Note: Source: Field Survey 2014.

\section{Number of Ponds Unit Owned}

Table 8 showed that the respondents with 1-5 units of pond have the highest percentage of 77.8. This might probably be due to lack of capital or shortage of land to expand the existing project.

\section{Rearing Facilities}

Table 9 showed that majority $(81.3 \%)$ of the respondents used earthen pond only; $17.5 \%$ used both concrete and earthen ponds while $1.3 \%$ used concrete pond only. It also reveals that most respondents in the study area prefer earthen pond due to the fact that the cost of construction and its maintenance is less expensive than other types.

\section{Nature of Damage of Flood on Ponds and Fishes}

Table 10a showed that flood majorly destroys ponds (46.3\%), followed by pollution of water (31.3\%), flood affects the water $\mathrm{pH}(13.8 \%)$ as well as oxygen depletion in the pond (8.8\%). Table $10 \mathrm{~b}$ also showed that flood has adverse effects on fishes, majorly through fish run-off $(43.1 \%)$, it is a major route of fish loss.

$\mathrm{BCR}$ : Table $11 \mathrm{~b}$ revealed that the $\mathrm{BCR}$ is greater than one. This ratio is one of the concepts of discount method of project evaluation. As a rule of thumb, any business with BCR greater than one, equal to one or less than one indicates profitable, break-even or loss respectively.

Rate of Returns (ROR): The rate of returns in fish production in the study area is .16. This shows that for every $\mathrm{N} 1$ invested, 16 kobo is gained by the respondents.

ESR: The value of the ratio is .39 which implies that about $39 \%$ of the TC of production is made up of FC component. This makes the business worthwhile since increase in the production with $\mathrm{VC}$ will increase the TR leaving the FC unchanged.

GRR: GRR of .87 indicates that for every $\mathrm{N} 1$ returns to fish farm enterprise, 87 kobo is being spent.

\section{Regression Analysis}

The analysis determined the relationship between dependent and independent variables. The $\mathrm{R}^{2}$ of .904 indicated that the estimated independent variables explained $90 \%$ of the variations in revenue to catfish farmers in the study area while the remaining $10 \%$ are exogenous to the system.

In $Y=b_{0}+b_{1} \ln X_{1}+b_{2} \ln X_{2}+b_{3} \ln X_{3}+b_{4} \ln X_{4}+$ $\mathrm{b}_{5} \ln \mathrm{X}_{5}+\mathrm{b}_{6} \ln \mathrm{X}_{6}+\mathrm{b}_{7} \ln \mathrm{X}_{7}+\mathrm{b}_{8} \ln \mathrm{X}_{8}+\mathrm{b}_{9} \ln \mathrm{X}_{9}+$ $\mathrm{b}_{10} \ln \mathrm{X}_{10}+\mathrm{b}_{11} \ln \mathrm{X}_{11}+\mathrm{E}$

In $\mathrm{Y}=-690711.4-30047.54 \ln \mathrm{X}_{1}-656362.8 \ln \mathrm{X}_{2}-$

$$
(-.26) \quad(-1.15) \quad(-1.02)
$$

$69795.69 \ln \mathrm{X}_{3}+0.375 \ln \mathrm{X}_{4}+1.114 \ln \mathrm{X}_{5}-$

$$
(-.59) \quad(.47)
$$

$2.468 \ln \mathrm{X}_{6}+1.478 \ln \mathrm{X}_{7}+0.576 \ln \mathrm{X}_{8}-25.929 \ln \mathrm{X}_{9}-$

$$
\begin{array}{llll}
(-.70) & (2.81) & (-.08) & (-.62) \\
458,766.851 & \ln \mathrm{X}_{10}+629.106 .6 & \operatorname{InX} \mathrm{X}_{11}+\mathrm{E} \\
& (-.70) & (1.98)
\end{array}
$$

From the above equation, five of the coefficients [that is, cost of land $\left(\mathrm{X}_{4}\right)$, cost of fingerlings $\left(\mathrm{X}_{5}\right)$, cost of feed $\left(\mathrm{X}_{7}\right)$, cost of transportation $\left(\mathrm{X}_{8}\right)$, and number of ponds $\left(\mathrm{X}_{11}\right)$ h have positive signs which mean that 
Table 10a. Frequency and Percentage Distribution Table Based on the Effects of Flood on Ponds

\begin{tabular}{lll}
\hline Effect of flood on ponds & Frequency & Percentage (\%) \\
\hline Pollution of the water & 25 & 31.3 \\
Change in water pH & 11 & 13.8 \\
Oxygen depletion in the pond & 7 & 8.8 \\
Damage of ponds & 37 & 46.3 \\
Total & 80 & 100 \\
\hline
\end{tabular}

Note: Source: Field Survey 2014.

Table 10b. Frequency and Percentage Distribution Table Based on the Effects of Flood on the Fishes

\begin{tabular}{lll}
\hline Effect of flood on fishes & Frequency & Percentage (\%) \\
\hline Death & 8.4 & 10.5 \\
Sickness & 10.9 & 13.6 \\
Mixing of fishes of different sizes & 26.1 & 32.6 \\
Others (fish run-off) & 34.5 & 43.1 \\
Total & 80 & 100 \\
\hline
\end{tabular}

Note: Source: Field Survey 2014.

Table 11a. Cost and Returns Analysis of Fish Farming in the Study Area ( $\mathrm{N}=80)$

\begin{tabular}{llll}
\hline Items & Amount (N) & Average amount $(\mathrm{N})$ & Total cost $\%$ \\
\hline Variable Cost (VC) & & & 6.7 \\
\hline Cost of fingerlings & $7,978,100$ & $99,726.3$ & 46.8 \\
Cost of feed & $56,209,000$ & $702,612.5$ & .4 \\
Cost of drugs & 477,500 & $7,827.9$ & 5.5 \\
Cost of labour & $6,549,000$ & $99,277.3$ & 2.1 \\
Cost of transportation & $2,560,000$ & $45,714.3$ & 61.5 \\
Total Variable Cost (TVC) & $73,773,600$ & $955,158.3$ & 28.4 \\
\hline Fixed Cost (FC) & & & 7.5 \\
\hline Startup capital & $34,140,000$ & $437,692.3$ & 2.6 \\
Cost of land & $9,032,000$ & $136,848.5$ & 38.5 \\
Cost of constructing a pond & $3,095,800$ & $56,287.3$ & 100 \\
Total Fixed Cost (TFC) & $46,267,800$ & $578,347.5$ & \\
Total Cost (TC) & $120,041,400$ & $1,500,517.5$ & \\
Total Revenue (TR) & $138,659,400$ & $1,733,242.5$ & \\
Gross Margin (GM) & $64,885,800$ & $8,110,072.5$ & \\
Profit & $18,618,000$ & 232,725 & \\
\hline
\end{tabular}

Note: Source: Field Survey, 2014. TR = Output * Unit Price; TC= TFC + TVC; GM = TR - TVC; Profit = GM - TFC.

Table 11b. Showing Various Profitability Ratios

\begin{tabular}{ll}
\hline Ratios & Values \\
\hline Benefit Cost Ratio (BCR) & 1.16 \\
Rate of Returns (ROR) & .16 \\
Expense Structure Ratio (ESR) & .39 \\
Gross Revenue Ratio (GRR) & .87 \\
\hline
\end{tabular}

Note: Source: Field Survey 2014. BCR = TR / TC; ESR = FC / TC; GRR = TC / TR; ROR = Profit / TC. 
Table 12. Regression Results of Factors Explaining Factors Affecting the Profitability of Fish Farming

\begin{tabular}{lll}
\hline Variable & Coefficients & T-value \\
\hline Constant & -690711.4 & -.26 \\
Age $\left(\mathrm{X}_{1}\right)$ & -30047.54 & -1.15 \\
Gender $\left(\mathrm{X}_{2}\right)$ & -656362.8 & -1.02 \\
Household size $\left(\mathrm{X}_{3}\right)$ & -69795.69 & -.59 \\
Cost of Land $\left(\mathrm{X}_{4}\right)$ & .375 & .47 \\
Cost of fingerlings $\left(\mathrm{X}_{5}\right)$ & 1.114 & .24 \\
Cost of labour $\left(\mathrm{X}_{6}\right)$ & -2.468 & -.70 \\
Cost of feed $\left(\mathrm{X}_{7}\right)$ & 1.478 & $2.81^{* * *}$ \\
Cost of transportation $\left(\mathrm{X}_{8}\right)$ & .576 & .08 \\
Cost of drugs $\left(\mathrm{X}_{9}\right)$ & -25.929 & -.62 \\
Effects of flood $\left(\mathrm{X}_{10}\right)$ & $-458,766.851$ & -.08 \\
Number of ponds $\left(\mathrm{X}_{11}\right)$ & $629,106.6$ & $1.98^{* *}$ \\
\hline
\end{tabular}

Note: Source: Field Survey, 2014. ${ }^{* *}$ significant at $1 \%$; ${ }^{* *}$ significant at $5 \%$; ${ }^{*}$ significant at $10 \%$.

Table 13. Percentage of Ibadan City Surface Impervious to Water Infiltration

\begin{tabular}{lllll}
\hline Sections of Ibadan City & \% in 1965 & \% in 1994 & \% increase & Rate of increase \\
\hline Traditional core & 15.4 & 42.5 & 27.1 & 1.80 \\
Modern low density & 4.3 & 17.3 & 13.0 & .98 \\
Modern high density & 11.2 & 30.2 & 19.0 & 1.20 \\
Utilities and reservations & 3.6 & 17.5 & 13.9 & 1.93 \\
Mean values & 9.5 & 28.4 & 18.9 & 1.31 \\
\hline
\end{tabular}

Note: Source: Field Survey, 2014.

Table 14. Analysis of Flooded Buildings and Those Within River/Stream Setbacks in the Eleven LGAs of Ibadan

\begin{tabular}{lllll}
\hline S/No. & Local government & $\begin{array}{l}\text { Numbers of buildings } \\
\text { within statutory } \\
\text { setback }\end{array}$ & $\begin{array}{l}\text { Numbers of buildings } \\
\text { flooded on August } \\
\text { 26, 2011* }\end{array}$ & $\begin{array}{c}\text { River/Stream } \\
\text { length (km) }\end{array}$ \\
\hline 1. & Akinyele & 2,527 & 382 & 435.57 \\
2. & Egbeda & 2,703 & 332 & 229.30 \\
3. & Ibadan North East & 4,621 & $22 \mathrm{~S}$ & 41.17 \\
4. & Ibadan North & 3,290 & 260 & 33.23 \\
5. & Ibadan North west & 4,543 & 162 & 60.09 \\
6. & Ibadan South East & 2,435 & 55 & 47.69 \\
7. & Ibadan Southwest & 3,931 & 369 & 75.35 \\
8. & Ido & 368 & 78 & 888.65 \\
9. & Lagelu & 913 & 68 & 274.15 \\
10. & Oluyoie & 366 & 63 & 663.01 \\
11. & Ona-Ara & 856 & 108 & 420.43 \\
& Total & 26,553 & 2,105 & $3,168.64$ \\
\hline
\end{tabular}

Note: Source: Field Survey, 2014.

an increase in any of the variables would increase the revenue of the respondents. The coefficients of age $\left(\mathrm{X}_{1}\right)$, gender $\left(\mathrm{X}_{2}\right)$, household size $\left(\mathrm{X}_{3}\right)$, cost of labour
$\left(\mathrm{X}_{6}\right)$, cost of drugs $\left(\mathrm{X}_{9}\right)$, and effect of flood $\left(\mathrm{X}_{10}\right)$ have negative signs which indicate a decrease in the TR as the variables increase (see Table 12). 


\section{CONCLUSIONS}

This research showed that majority of the fish farmers were within the age bracket of 40-49 years, the bulk of those who are involved in aqua-cultural business were in their active age, and most of them were males $(82.5 \%)$. Having more male fish farmers than female counterparts implies that fish farming activities are gender sensitive/biased. Hence, the state has potential to sustain fish farming for many more years. The study revealed that some of the factors that contribute to flood in the study area are: the type of rainfall, topography of the land, vegetation, river, dam, and the methods of waste disposal. Cost and returns analysis and profitability ratio were employed to determine the profitability of fish farming. The empirical results show that, an average GM and Profit which were $\mathrm{N} 8,110,072.5$ and $\mathrm{N} 232,725$ respectively, were obtained from the study. The rate of returns in fish production in the study area is .16 . This shows that for $\mathrm{N} 1$ is invested, 16 kobo is gained by the respondent and a gross revenue ratio of .87 indicates that for every one naira returning to fish farm enterprise, 87 kobo is being spent; this also confirmed the profitability of the fish farming. Regression analysis was used to identify the effect of flood explosion on fish farming and other factors that influenced fish farming. The value of $\mathrm{R}^{2}$ obtained (.904) indicated that $90 \%$ of the variation in the revenue (Y) was explained by the estimated independent variables $\left(\mathrm{X}_{1}-\mathrm{X}_{11}\right)$. Based on the findings of the study, the following recommendations were made to promote catfish production in the study area:

The advisory services of extension agencies are valuable in the production of catfish; more extension workers should be employed to give the technical knowledge to fish farmers on how to use some equipment and dissemination of new innovations on how to improve their fish farming system and productivity with proper managements of flooding problems.

\section{Contributions to the Knowledge}

From the observation, it was noted and confirmed that some ponds had actually been adversely affected by floods; the Nigeria Meteorological Agency (NIMET) has predicted that there will be very heavy rains and flooding in a number of states in Nigeria in 2014/2015. Since Ibadan is specifically mentioned, there is need to lay emphasis on effective management of floods. This study hereby encourages people in Ibadan to stop indiscriminate dumping of refuse and solid wastes in order to stop the problem constituting blockage of river, stream channels, and artificial drainage channels. The problem of improper management must be solved to eliminate this cause of flooding.

\section{References}

Abam, T. S. K. 2006. "Development Policy Framework for Erosion and Flood Control in Nigeria." EARTHWATCH-Magazine for Environment and Development Experts in Nigeria 5(1):25-32.

Adebayo, O. O. 2012. "Determinants of Extension Service Needs of Catfish Farmers in Oyo State, Nigeria (A Case Study of Ido Local Government Area)." Journal of Humanities and Social Science 1(4):54-58.

Bradshaw, C., N. Sodhi, H. Peh, and W. Brook. 2007. "Global Evidence That Deforestation Amplifies Flood Risk and Severity in the Developing World." Global Change Biology 13(11):2379-2395.

Brummett, R. E., J. L. N. Youaleu, A.-M. Tiani, and M. M. Kenmegne. 2010. “Women's Traditional Fishery and Alternative Aquatic Resource Livelihood Strategies in the Southern Cameroonian Rainforest." Fisheries Management and Ecology 17(3):221-230.

Ekong, E. E. 2003. An Introduction to Rural Sociology. 2nd ed. Uyo, Nigeria: Nigeria Dove Educational Publishers.

Etuonovbe, A. K. 2011. The Devastating Effect of Flooding in Nigeria. Retrieved (http://fig.net/resources/proceedings/fig proceedings/fig2011/papers/ts06j/ts06j_etuonovbe_5002.pd f).

Fakoya, E. O. 2000. "Farmers Use of Sustainable Land Management Practices in Ondo State, Nigeria." Unpublished PhD dissertation, Department of Agricultural Extension and Rural Development, University of Ibadan, Nigeria.

Lenat, D. R., D. L. Penrose, and K. W. Eagleson. 1981. "Variable Effects of Sediment Addition on Stream 
Benthos." Hydrobiologia 79:187-194.

Nwafor, J. C. 2006. Environmental Impact Assessment for Sustainable Development: The Nigerian Perspective. Enugu, Nigeria: EL 'DEMAK Pubs.

Oladoja, M. A., S. F. Adedoyin, and O. A. Adeokun. 2008. "Training Needs of Fisherfolks on Fishing Technologies." Journal of Food, Agriculture and Environment Science and Technology 6(1):195-198.

Sikiru, B. O., N. M. Omobolanle, B. J. O. Ayorinde, and O. O. Adegoke. 2009. "Improving Clarias Productivity Towards Achieving Food Security in Ijebu-Ode, Ogun State, Nigeria: A Socioeconomic Analysis." Advances in Biological Research 3(1-2):24-28.

Wikipedia. 2014. Ibadan City. Retrieved (http://en. m.wikipedia.org/wiki/ibadan).

Williams, S. B., R. O. Kareem, and O. A. Ojolowo. 2012. "Economic Analysis of Catfish Production in Ile-Ife, Osun State, Nigeria." Journal of Human Ecology 40(1):1-7.

\section{Bios}

Ayinde Alani Ezekiel, Ph.D., Department of Agricultural Economics, Faculty of Agricultural Sciences, Ladoke Akintola University of Technology, Nigeria; research field: environmental economics.

Timothy Abiodun Adebayo, Ph.D., Department of Crop and Environmental Protection, Faculty of Agricultural Sciences, Ladoke Akintola University of Technology, Nigeria; research fields: hydroengineering/environmental geology.

Abosede Olufunmi Adewoye, Ph.D., Department of Earth Sciences, Faculty of Environmental Sciences, Ladoke Akintola University of Technology, Nigeria; research field: environmental entermology.

Akinniran Taiwo Nureni, Ph.D., Department of Agricultural Economics, Faculty of Agricultural Sciences, Ladoke Akintola University of Technology, Nigeria; research fields: agribusiness and finance. 